\title{
An outbreak of measles in gold miners in River Nile State, Sudan, 2011
}

Amel A. Sulaiman, ${ }^{1}$ Wadie M. Elmadhoun, ${ }^{2}$ Sufian K. Noor, ${ }^{3}$ Ahmed O. Almobarak, ${ }^{4}$ Sarra O. Bushara, ${ }^{3}$ Meissa M. Osman, ${ }^{5}$ Heitham Awadalla ${ }^{6}$ and Mohamed H. Ahmed 7

${ }^{1}$ Department of Community Medicine, College of Medicine, Nile Valley University, Atbara, Sudan. ${ }^{2}$ Department of Pathology and Microbiology, Faculty of Medicine, Nile Valley University, Atbara, Sudan. ${ }^{3}$ Department of Internal Medicine, Faculty of Medicine, Nile Valley University, Atbara, Sudan. ${ }^{4}$ Department of Pathology, Faculty of Medicine, University of Medical Sciences and Technology, Khartoum, Sudan. ${ }^{5}$ Department of Paediatrics, University Hospital of Leicester, Leicester, United Kingdom. ${ }^{6}$ Department of Community Medicine, Faculty of Medicine, University of Khartoum, Khartoum, Sudan. ${ }^{7}$ Department of Medicine and HIV Metabolic Clinic, Milton Keynes University Hospital NHS, Foundation Trust, Eaglestone, Milton Keynes, United Kingdom. (Correspondence to: Mohamed Ahmed: elziber@yahoo.com).

\section{Abstract \\ Background: Despite the wide use of vaccination, measles outbreaks still occur.}

Aims: This study assessed cases notified during a measles outbreak in northern Sudan in 2011 and the response of the health authorities to contain the outbreak.

Methods: The records of all measles cases reported to the River Nile State health ministry in 2011 from the Abu Hamad locality, a gold-mining area, were reviewed together with the actions of the health authorities at the time of the outbreak. Seventeen gold-mining clusters were included. Data on demographic, clinical, geographic and chronological characteristics of the cases were extracted.

Results: The outbreak occurred from 27 January to 3 May 2011 with the peak in epidemiological week 9. A total of 445 measles cases were recorded, giving an incidence of 27.1 per 10000 of the mining and resident population. Most cases (87.4\%) were aged between 15 and 34 years. High fever was the most common symptom ( $99.3 \%$ of the cases), followed by conjunctivitis (80.4\%); haemorrhage was recorded in $29.4 \%$. Most cases (84.9\%) were unvaccinated. Six deaths occurred (case fatality: 1.3\%); two from cerebral coma and four from haemorrhagic shock. Severity of disease was significantly associated with place of origin of the cases $(P=0.003)$.

Conclusion: The measles outbreak in the gold-mining areas in Abu Hamad had serious consequences attributed to poor environmental conditions, overcrowding, poor nutrition and lack of vaccination. The health authority response helped end the outbreak. The local health authority should consider the gold-mining areas as a potential risk to public health in their future plans.

Keywords: measles, disease outbreaks, mining, Sudan

Citation: Sulaiman A; Elmadhoun W; Noor S; Almobarak A; Bushara S; Osman M et al. An outbreak of measles in gold miners in River Nile State, Sudan, 2011. East Mediterr Health J. 2020;26(2):152-160. https://doi.org/10.26719/2020.26.2.152

Received: 29/07/17; accepted: 04/06/18

Copyright (C) World Health Organization (WHO) 2020. Open Access. Some rights reserved. This work is available under the CC BY-NC-SA 3.o IGO license (https://creativecommons.org/licenses/by-nc-sa/3.o/igo).

\section{Introduction}

Measles is a serious infectious disease affecting all age groups, particularly children under 5 years (1-3). An individual with measles can spread the infection to healthy contacts a few days before and after the onset of the rash. Once recovered from measles, immunity is life-long $(4,5)$. A suspected outbreak of measles is defined as "the occurrence of five or more reported suspected cases of measles in one month per 100 ooo population living in a geographical area (e.g. district/block)" (6). A confirmed measles outbreak is defined as "the occurrence of three or more confirmed measles cases (at least two of which should be laboratory-confirmed; IgM positive) in a health facility/district/block (approximate catchment population of 100 000) in a month" (6).

The measles vaccine is one of the best public health strategies to reduce morbidity and mortality caused by measles. During 2000-2017, the annual reported measles incidence decreased $83 \%$, from 145 to 25 cases per million population (7) and the estimated number of measles cases and deaths declined by $80 \%$ (7-10). Despite global immunization efforts, outbreaks in developed and developing countries have been recorded, which are attributed to pockets of a population where vaccination coverage is low $(11,12)$.

A well-established case surveillance system can ensure early detection, investigation and confirmation of every suspected measles case in a community (13). Detection of an outbreak relies on the ability of the responsible authority to recognize an increase in measles cases significantly above the number normally expected. Response to measles outbreaks includes immunization, case management and raising public awareness (14).

Sudan is a sub-Saharan African country with a population of 33419000 people (2011 census) (15). The country started measles vaccination in 1985 (16). A measles elimination programme was adopted at both the national level and state levels. During 2004, River Nile State implemented four strategies to eliminate measles through catch-up and follow-up vaccination campaigns which achieved 100\% coverage. A second dose 
of the measles vaccine was introduced in 2012 and is recommended to be given at 18 months of age (17). Sudan adopted the guidelines of the World Health Organization (WHO) and United Nations Children's Fund (UNICEF) for childhood immunization, and immunization coverage reached $85 \%$ of children aged one year in 2012 (18). As with other complications of measles, the risk of death is highest in children and young adults (19).

The aim of this report was to review the notified cases of measles during a measles outbreak that occurred in the traditional (non-organized, rural) gold-mining areas in Abu Hamad, River Nile State, north Sudan in 2011 and document the response of the health authority.

Documentation of this outbreak is important because of its occurrence in an unusual setting. The gold miners worked in remote and poor areas where essential health services are lacking, and there is constant movement in and out of the areas. Most of the miners came from the western part of Sudan where vaccination rates are low. These factors may disturb the measles herd immunity. Some of the cases presented with haemorrhagic symptoms which are rarely reported in the literature during the measles outbreak. This report also documents the interventions taken to contain the outbreak. In light of the outbreak, it is important that the local health authority consider the gold-mining areas as one of the potential risks for public health in their future plans.

\section{Methods}

\section{Study setting}

River Nile State is in the northern part of Sudan and covers an area of $122123 \mathrm{~km}^{2}$. It has a population of 1190578 (2010) (15). The state borders Egypt in the north, Northern and North Darfur States in the west, Red Sea and Kassala states in the east and Khartoum State in the south. River Nile State has six localities (Abu Hamad, Berber, Atbara, Ad Damar, Shendi and Al Matamma). Abu Hamad was the most affected by the 2011 measles outbreak, especially those working in gold mining. Abu Hamad is in the northern part of the state and has a population for 69056 (5.5\% of the total population of River Nile State), in addition to an estimated 95029 gold miners who come from different parts of Sudan or neighbouring countries. According to the River Nile State unpublished EPI report, 2011-2012, the age distribution of the Abu Hamad population was as follows: 9.4\% were < 1 year, $17.3 \%$ were $1-5$ years, $34.6 \%$ were $6-15$ years and $38.7 \%$ were $>15$ years.

The gold-mining areas are located in the desert far from the urban areas on the banks of the River Nile. At the time of the outbreak, there were 17 gold-mining areas, the biggest of which was Gabgaba where most of the measles cases were reported. The area is characterized by overcrowding, poor health infrastructure and poor hygiene facilities. All these factors have a negative impact on the public health (20).
The River Nile State health system provides both curative and preventive health services through the public and private sector. The public health facilities for River Nile State include 33 hospitals and 318 primary health care centres as well as three military and two police hospitals (21). The private health facilities include three hospitals and five health centres. In Abu Hamad locality, there is one public sector hospital, 10 public sector primary health care centres and one private health care centre.

Sudan has a good surveillance system for infectious diseases. The Federal Ministry of Health has a wellestablished Expanded Programme on Immunization (EPI) that provides vaccination services free of charge to all the population. This programme has had a system of case-based and laboratory-based surveillance to monitor measles cases and deaths since 2006. Good-quality surveillance has been maintained in 30 sentinel sites.

During this outbreak, the health ministry of River Nile State, with support from the Federal Ministry of Health, monitored and coordinated the outbreak control activities in Abu Hamad locality, mainly in the goldmining areas where the outbreak occurred.

\section{Surveillance and case definition of measles}

In Sudan, measles is a disease that requires mandatory notification. The local health authorities report suspected and confirmed measles cases to the Federal Ministry of Health monthly. During the 2011 outbreak, this procedure was modified within a few days of onset of measles in the index case on 1 February 2011. Physicians and medical assistants working in both public and private sectors in the state were notified through official letters and mobile telephone numbers and were asked to report suspected measles cases to both the local health authorities and the State health ministry within 24 hours. Local health authority personnel made an epidemiological investigation of suspected cases including laboratory investigations and contact-tracing.

A suspected measles case was defined as any person within the Abu Hamad locality with a fever $\left(\geq 38^{\circ} \mathrm{C}\right)$, generalized rash and at least one of the following symptoms: cough, coryza or conjunctivitis during the period 27 January to 3 May 2011. A confirmed case was defined either as a laboratory-confirmed case or a case with an epidemiological link to a confirmed case (22). Line listing was done which included the demographic and clinical characteristics of each suspected case, vaccination history, date of onset of symptoms and outcome. For calculation of the cumulative measles incidence rate, we divided the number of suspected cases reported through the surveillance system during the outbreak period (2011) by the estimated population of Abu Hamad locality plus the estimated number of miners and multiplied by 10000 (23). A daily bulletin was prepared and sent to the Federal Ministry of Health with information on age, sex, case fatality rate and control measures implemented. The data from these bulletins were used for our report. The Federal 
Ministry of Health and the WHO country office in Khartoum sent a mission with experts from EPI, the epidemiology department of the Federal Ministry of Health and the national public health laboratory. Together with the State health ministry team, they visited Abu Hamad hospital and some of the goldmining areas. An action plan was put in place to contain the outbreak. All outbreak investigation steps and control activities were supported by the Federal Ministry of Health.

\section{Statistical analysis}

Data were cleaned and entered into Microsoft Excel and then converted to SPSS, version 21. The chi-squared test was used to compare associations between proportions, such as the deaths, and other variables, e.g. age, symptoms and workplace. A P-value $\leq 0.05$ was considered statistically significant.

\section{Ethical considerations}

Ethical approval was obtained from the Ethical Committee of the College of Medicine, Nile Valley University and State Ministry of Health. All personal data were kept confidential and used only for the purpose of the study.

\section{Results}

\section{Epidemiological characteristics}

The outbreak occurred mainly in 17 gold-mining areas of Abu Hamad locality and lasted from 31 January to 3 May 2011. A total of 445 cases were reported, giving an incidence of 27.1 per 10000 of the mining and resident population. Of the 445 cases, 25 were suspected cases that had no epidemiological links, 22 were laboratory-confirmed cases and an epidemiological link was found in 398 cases.

The male to female ratio of cases was $27: 1$. The mean age of cases was 25.5 (standard deviation 7.4) years, and young adults aged 15-34 years were the most affected age group, 389 ( $87.4 \%$ ) (Table1). The place of origin of the cases differed; most had migrated from other states of Sudan (mostly North Kordofan State in western Sudan), and a few cases were from neighbouring countries such as Eritrea and Ethiopia (Table 1). Gabgaba, which is the biggest of the gold-mining areas in the locality, had the greatest proportion of cases, $133(29.9 \%)$ and Al Galah and $\mathrm{Al}$ Gouz had the fewest, with one case $(0.2 \%)$ each (Table 1).

Of the 445 notified cases, $378(85 \%)$ were unvaccinated (Table 2). A statistically significant association was found between age group and vaccination status $(P<0.001)$ (Figure 1).

\section{Clinical presentation}

Table 2 shows the symptoms, complications and haemorrhagic symptoms of measles cases. About a third of the cases (35.7\%) experienced loss of consciousness and two (0.4\%) went into a coma. No statistically significant correlation was found between age and clinical characteristics of the patients $(P>0.05)$.
Table 1 Sociodemographic characteristics of notified measles cases, Sudan, 2011

\begin{tabular}{|c|c|c|}
\hline Characteristic & No. & $\begin{array}{c}\% \\
(n=445)\end{array}$ \\
\hline \multicolumn{3}{|l|}{ Sex } \\
\hline Male & 429 & 96.4 \\
\hline Female & 16 & 3.6 \\
\hline \multicolumn{3}{|l|}{ Age group (years) } \\
\hline$<1$ & 1 & 0.2 \\
\hline $1-4$ & 1 & 0.2 \\
\hline $5-14$ & 13 & 2.9 \\
\hline $15-24$ & 197 & 44.3 \\
\hline $25-34$ & 192 & 43.1 \\
\hline $35-44$ & 28 & 6.3 \\
\hline$\geq 45$ & 13 & 2.9 \\
\hline \multicolumn{3}{|l|}{ Place of origin $(n=423)$} \\
\hline North Kordofan State & 203 & 48.0 \\
\hline River Nile State & 51 & 12.1 \\
\hline South Darfur State & 46 & 10.9 \\
\hline North Darfur State & 28 & 6.6 \\
\hline Khartoum State & 25 & 5.9 \\
\hline El Gezira State & 20 & 4.7 \\
\hline Kassala State & 9 & 2.1 \\
\hline West Darfur State & 9 & 2.1 \\
\hline Northern State & 7 & 1.7 \\
\hline Sennar State & 6 & 1.4 \\
\hline Gedaref State & 5 & 1.2 \\
\hline South Kordofan State & 4 & 0.9 \\
\hline Ethiopia & 4 & 0.9 \\
\hline West Kordofan State & 2 & 0.5 \\
\hline Eritrea & 2 & 0.5 \\
\hline Blue Nile State & 1 & 0.2 \\
\hline Red Sea State & 1 & 0.2 \\
\hline \multicolumn{3}{|c|}{ Residence in gold-mining area } \\
\hline Gabgaba & 133 & 29.9 \\
\hline Twaheen & 101 & 22.7 \\
\hline Namira & 72 & 16.2 \\
\hline Alkhala & 34 & 7.6 \\
\hline Aldahab company & 21 & 4.7 \\
\hline Shalateen & 21 & 4.7 \\
\hline Abu Hamad town & 15 & 3.4 \\
\hline Alnabia & 15 & 3.4 \\
\hline Kurgus & 9 & 2.0 \\
\hline Egypt border & 7 & 1.6 \\
\hline Atbara & 3 & 0.7 \\
\hline Umserah & 4 & 0.9 \\
\hline Wadi Arab & 3 & 0.7 \\
\hline Hourse Naseb & 3 & 0.7 \\
\hline Al Hush & 2 & 0.4 \\
\hline Al Galah & 1 & 0.2 \\
\hline Al Gouz & 1 & 0.2 \\
\hline
\end{tabular}




\begin{tabular}{|c|c|c|c|c|}
\hline \multirow[t]{2}{*}{ Characteristic } & \multicolumn{2}{|c|}{ Yes } & \multicolumn{2}{|c|}{ No } \\
\hline & No. & $\%$ & No. & $\%$ \\
\hline \multicolumn{5}{|l|}{ Symptoms } \\
\hline Fever & 442 & 99.3 & 3 & 0.7 \\
\hline Conjunctivitis & 358 & 80.4 & 87 & 19.6 \\
\hline Arthralgia & 348 & 78.2 & 97 & 21.8 \\
\hline Myalgia & 275 & 61.8 & 170 & 38.2 \\
\hline Backache & 337 & 75.7 & 108 & 24.3 \\
\hline Anorexia & 432 & 97.1 & 13 & 2.9 \\
\hline Headache & 365 & 82.0 & 80 & 18.0 \\
\hline \multicolumn{5}{|l|}{ Complications } \\
\hline Pneumonia & 376 & 84.5 & 69 & 15.5 \\
\hline Blurring of vision & 337 & 75.7 & 108 & 24.3 \\
\hline Loss of consciousness & 159 & 35.7 & 286 & 64.3 \\
\hline Coma & 2 & 0.4 & 443 & 99.6 \\
\hline \multicolumn{5}{|l|}{ Haemorrhagic symptoms ${ }^{a}$} \\
\hline Haematemesis & 131 & 29.4 & 314 & 70.6 \\
\hline Melena & 107 & 24.0 & 338 & 76.0 \\
\hline Haemoptysis & 103 & 23.1 & 342 & 76.9 \\
\hline Epistaxis & 97 & 21.8 & 348 & 78.2 \\
\hline Haematuria & 32 & 7.2 & 413 & 92.8 \\
\hline Characteristic & \multicolumn{2}{|c|}{ No. } & \multicolumn{2}{|c|}{$\%$} \\
\hline \multicolumn{5}{|l|}{ Vaccination status } \\
\hline Vaccinated & \multicolumn{2}{|c|}{67} & \multicolumn{2}{|c|}{15.1} \\
\hline Not vaccinated & \multicolumn{2}{|c|}{378} & \multicolumn{2}{|c|}{84.9} \\
\hline \multicolumn{5}{|l|}{ Sample taken } \\
\hline No & \multicolumn{2}{|c|}{4} & \multicolumn{2}{|c|}{0.9} \\
\hline Yes & \multicolumn{2}{|c|}{29} & \multicolumn{2}{|c|}{6.5} \\
\hline Unknown & \multicolumn{2}{|c|}{412} & \multicolumn{2}{|c|}{92.6} \\
\hline \multicolumn{5}{|l|}{ Outcome } \\
\hline Survived & \multicolumn{2}{|c|}{439} & \multicolumn{2}{|c|}{98.7} \\
\hline Died & \multicolumn{2}{|c|}{6} & \multicolumn{2}{|c|}{1.3} \\
\hline
\end{tabular}

${ }^{a}$ Multiple answers were possible.

Of the 445 cases, 186 (41.8\%) were admitted to hospital and the average length stay was 5 days. Routine laboratory investigations were done for all cases admitted to hospital, including haematological and biochemical tests. The blood samples were tested by ELISA. For samples that were not conclusive, then real-time polymerase chain reaction was done. These tests are done in the National Public Health Laboratory at Khartoum. Specific tests for measles (real-time polymerase chain reaction and IgM) were conducted for only 29 cases (Table 2). This was because of the scarcity of laboratory resources so priority was for well-prepared samples - bad packing of samples and maintenance of the cold chain during transportation were challenges. The measles tests gave positive results for $76 \%(22 / 29)$ of the cases tested. All cases admitted to hospital were managed based on their symptoms. Most of the patients recovered and were discharged. However, six cases died between 16 and 28 February 2011, all of whom were males, giving an overall case fatality rate of $1.3 \%$. Four of the six patients who died were unvaccinated. The highest case fatality rate was in the age group $\geq 45$ years $(7.7 \%)$, followed by children aged $1-14$ years $(6.7 \%)$, then adult's aged $35-44$ years (3.6\%), and finally young adults aged $15-34$ years $(0.8 \%)$.

The severity of measles was strongly associated with outcome, gold-mining area and place of origin. Two measles cases went into a coma and died; one of these cases was younger than 14 years and the second was in the age group $25-34$ years $(P<0.001)$. Four measles cases with haemorrhage died $(P=0.014)$. The highest numbers of reported cases were from Gabgaba and these case were also the most severe $(P=0.015)$. A statistically significant association was found between severity of disease and place of origin of the cases $(P=0.003)$.

\section{Measles outbreale}

The first reported case (index case) was a 33-year-old Sudanese national. He had migrated from the western part of Sudan for work and worked mainly in Gabgaba. He felt sick on 27 January 2011 and was admitted to hospital on 28 January with a skin rash, fever, conjunctivitis, cough, headache, anorexia, myalgia and backache. He was unvaccinated. Analysis of routine data allowed an additional case to be identified that had been notified in the same place. Many of the measles cases $(n=133)$ came from the same mining area (Gabgaba) as the index case. This measles outbreak spread rapidly in large areas because of overcrowding, poor environmental conditions and malnutrition. The outbreak started in epidemiological week 4 and ended in week 18, 2011 (Figure 2). The highest number of cases (peak) was reported on 1 March (week 9) and then the numbers continued to decline until 3 May 2011 (week 18) after isolation of cases and implementation of other control measures (Figure 3).

\section{Outbrealc response}

In response to the clusters of measles cases, active tracing of susceptible contacts was done by the local health authority. An outbreak investigation was launched at the gold-mining areas in Abu Hamad locality especially in areas reporting many cases (Table 1). A public awareness campaign was implemented at the most seriously affected places (during week 9 until week 18). This campaign was done with media support. Physicians were urged to play their part, and the telephone numbers of the state epidemiology director and state EPI coordinator were made available to physicians for further information or any kind of support. In addition, mobile cinema shows were used to raise awareness, lectures were given and pamphlets were distributed to the public mainly in the markets and areas where people gather. The key messages included early reporting to the hospital any cases of skin rash, fever, haemorrhage or any unexplained sign or symptom, avoidance of overcrowded areas, the importance of vaccination, and the importance of early diagnosis to prevent complications. 


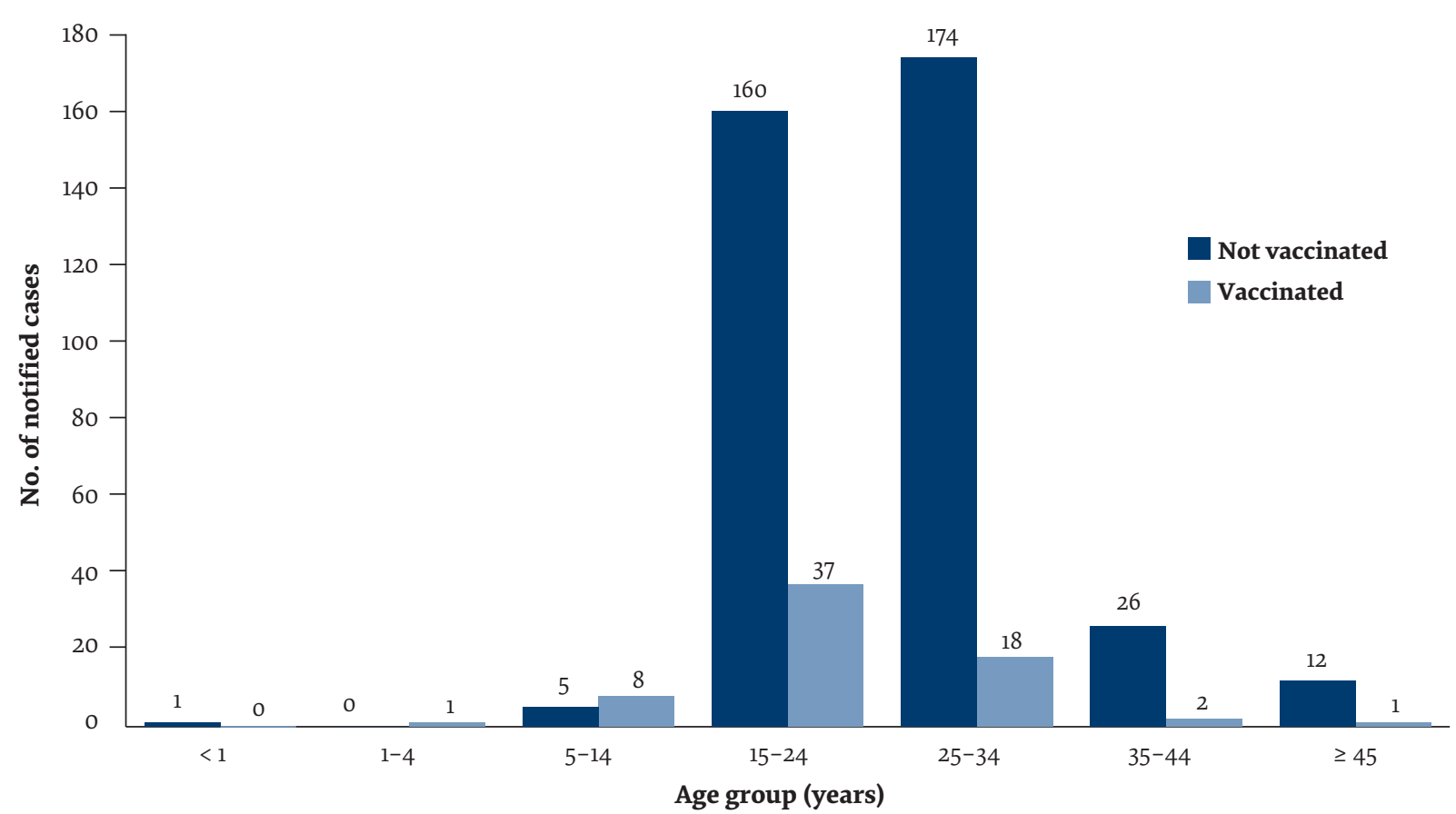

Figure 1 Age distribution of notified measles cases according to vaccination status, Sudan, $2011(n=445, P<0.001)$

In addition, a vaccination campaign was conducted by the health authorities following confirmation of the measles outbreak. The campaign had two parts depending on the targeted groups. The main campaign targeted the gold-mining areas where miners were distributed over a very large area in the desert. For this part, well-prepared mobile teams were needed. The second part of the campaign targeted the urban community of Abu Hamad. The targeted population for the vaccination campaign was 95029 people.
Vaccination coverage was $67.6 \%$, which was less than expected because the gold miners were often moving and the population itself changed. All suspected and confirmed cases were managed free of charge as is the usual practice in the case of outbreaks.

\section{Discussion}

The measles outbreak in 2011 occurred in gold miners in Abu Hamad locality in River Nile State with 445 cases reported from the end of January to 1 May. This outbreak

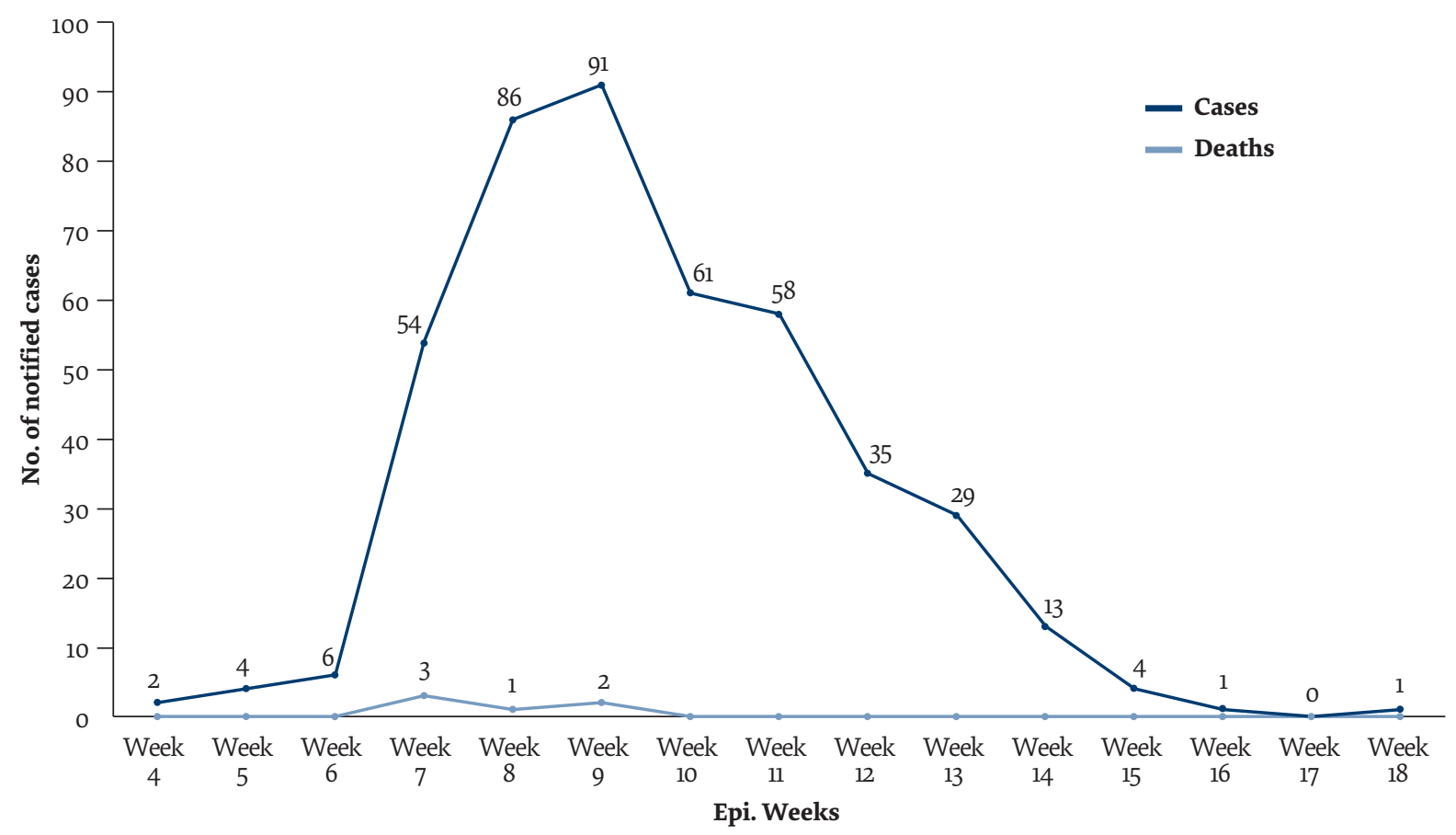

Figure 2 Trend of measles cases and deaths over the epidemiological weeks of the outbreak, Sudan, 2011 


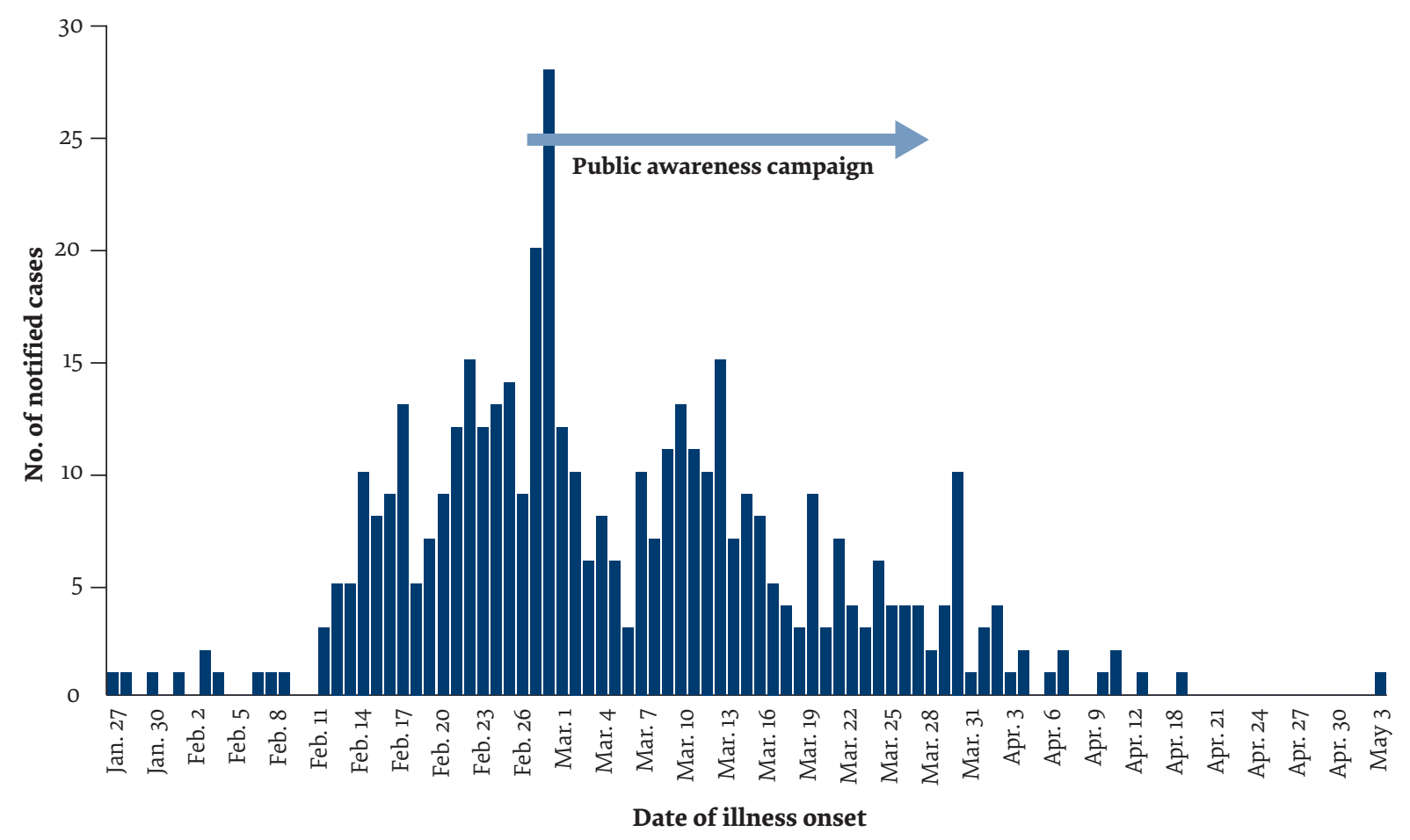

Figure 3 Epidemiological curve of cases during the measles outbreak, Sudan, 2011

occurred mainly among young adult men from different geographical and demographic backgrounds who lived in crowded housing in the gold-mining region. Quite a large proportion of the cases had haemorrhagic symptoms suggesting a severe form of measles (haemorrhagic measles) characterized by dark, haemorrhagic skin eruptions, which is generally rare (19).

Because of the widespread use of measles vaccination, the incidence of measles has fallen worldwide (24). However, measles continues to circulate in many countries and remains one of the leading killers of children globally (9). In the 2011 outbreak in Sudan, the case fatality rate $(1.3 \%)$ was significantly associated with age $(P<0.001)$ with the highest rate in those more than 45 years $(7.7 \%)$. This shifting of measles deaths to the older age group could be because the affected population was mostly gold miners. This upward shift is consistent with an outbreak that occurred in Bavaria, Germany in 2007 (25). This can be explained by non-vaccination or suboptimal measles vaccination coverage and a delay in implementing follow-up supplementary immunization activities (26). Moreover, migration of young people from areas with low vaccination coverage to the goldmining areas can threaten herd immunity and increase the likelihood of infectious disease outbreaks $(4,14)$. Nonetheless, about $15 \%$ of the measles cases in the 2011 outbreak were vaccinated but scientists are still not entirely sure why certain individuals who are fully vaccinated get the measles. However, due to biological and environmental factors, individuals' immune systems can respond differently.

Geographically the outbreak of measles occurred in rural areas, mainly in the gold-mining areas, rather than the urban areas of Abu Hamad locality. The association between severity of disease and place of origin could be due to the low immunization status of individuals from these areas compared with those coming from and living in North Sudan.

Outbreaks affecting young adults and older people pose several challenges for control because these individuals are highly mobile, especially in goldmining areas, and they have more social contacts beyond their family than young children. This explains the rapid progression of this outbreak. Despite the efforts of the local health authority to implement isolation measures, raise awareness of the community, and publicize advice to the population to check and update their vaccination status, the outbreak lasted for 14 weeks (epidemiological weeks 4 to 18). Because of logistics and financial issues, it took longer for local health authorities to put in place sufficient control measure, so the response was delayed. Two supplementary vaccination campaigns were carried out, which is in line with WHO recommendations which strongly advise supplementary immunization activities during outbreaks in closed communities or institutions (27). A study in Africa showed that mass vaccination campaigns could slow epidemic spread of a disease even in urban settings (28).

In the 2011 outbreak in Sudan, $85 \%$ of the cases were unvaccinated which may be because of many contributing factors such as poor accessibility of health facilities, complex logistics, weak health systems, lack of government funding, civil unrest and displaced persons, especially in the eastern states of Sudan as most cases came from these areas. 
There were some limitations to the data available. The vaccination status of cases was based on patient recall; therefore, recall bias might have occurred. The available line list did not provide full information on duration of hospital admission which would have been useful for reporting further complications that occurred for cases.

\section{Conclusion}

The measles outbreak in the gold-mining areas of Abu Hamad locality was associated with serious consequences which could be attributed to poor environmental conditions, overcrowding, poor nutrition and lack of vaccination. The health authority response helped bring the epidemic to an end.

\section{Acknowledgements}

We thank the staff in the Department of Public Health and Surveillance in the health ministry of River Nile State for their data sharing and assistance.

Amel A. Sulaiman' affiliation is now: Family Medicine Academy, Qassim Health Cluster, Al Qassim Region, Saudi Arabia.

Funding: None.

Competing interests: None declared.

\section{Flambée de rougeole chez des mineurs d'or de l'État du Nil (Soudan) en 2011 Résumé}

Contexte : Malgré le recours généralisé à la vaccination, des flambées de rougeole surviennent toujours.

Objectifs : La présente étude a évalué les cas notifiés lors d'une flambée de rougeole dans le nord du Soudan en 2011 ainsi que la réaction des autorités sanitaires pour endiguer cette flambée

Méthodes : Les dossiers de l'ensemble des cas de rougeole notifiés au ministère de la Santé de l'État du Nil en 2011 par la localité d'Abu Hamad, zone d'exploitation minière aurifère, ainsi que les mesures d'intervention des autorités sanitaires au moment de la flambée, ont été examinés. Au total, 17 groupements de mines d'or ont été inclus. Des données sur les caractéristiques démographiques, cliniques, géographiques et chronologiques ont été extraites.

Résultats : La flambée est survenue du 27 janvier au 3 mai 2011, le pic ayant été atteint durant la neuvième semaine épidémiologique. Au total, 445 cas de rougeole ont été enregistrés, soit une incidence de 46,8 pour 10000 parmi la population de mineurs. La majorité des cas (87\%) étaient âgés de 15 à 34 ans. Une forte fièvre était le symptôme le plus courant (99,3\% des cas), suivi par une conjonctivite (80,4\%). Une hémorragie a été rapportée dans $29,4 \%$ des cas. La plupart des cas $(84,9 \%$ ) n'étaient pas vaccinés. Six décès sont survenus (taux de létalité : 1,3\%); deux étaient dus à un coma cérébral et quatre à un choc hémorragique. Une relation statistiquement significative a été constatée entre la sévérité de la maladie et l'origine géographique des cas ( $p=0,003)$.

Conclusions : La flambée de rougeole dans les zones d'exploitation minière aurifère de la localité d'Abu Hamad était associée à de graves conséquences, dues à des conditions environnementales défavorables, à la promiscuité, à une mauvaise alimentation et à une vaccination insuffisante. L'intervention des autorités sanitaires a permis d'enrayer la flambée.

$$
\begin{aligned}
& \text { وباء الحصبة في صفوف عهال مناجم الذهب في ولاية نهر النيل، السودان، } 1 \text { ب ب } \\
& \text { أمل سُليهان، وديع المدهون، سُفيان نور،أحمد المبارك، سارة بشارة، ميساء عثمان، هيثم عوض الله، محمد أحمد } \\
& \text { الخالاصة } \\
& \text { الخلفية: على الرغم من استعمال اللقاح المضاد للحصبة على نطاق واسع، فما زالت أوبئة الحصبة تحدث. }
\end{aligned}
$$

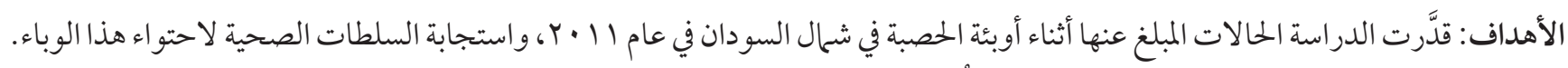

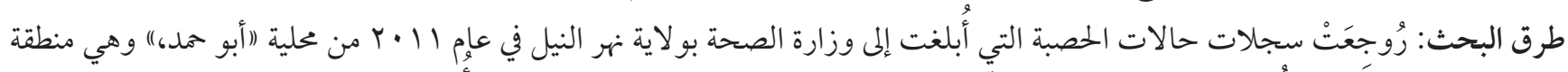

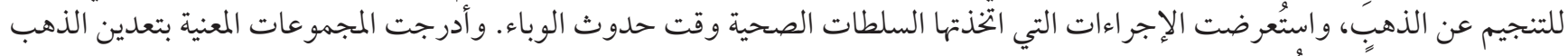

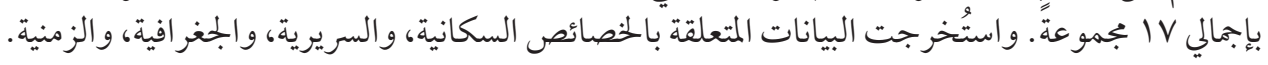

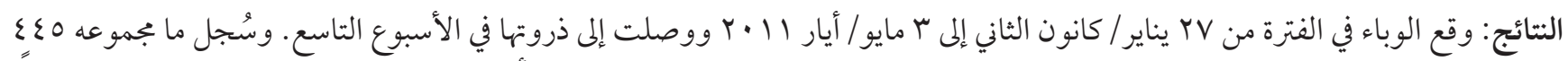

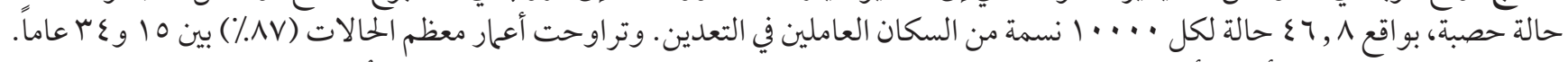

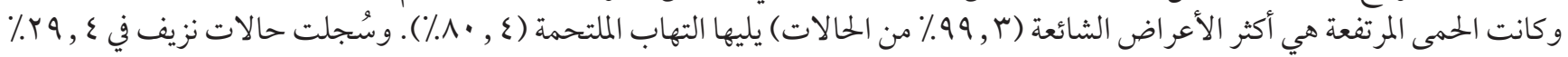




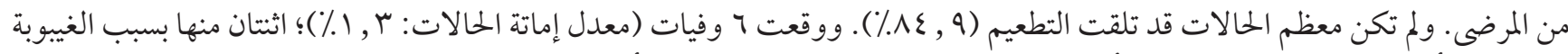

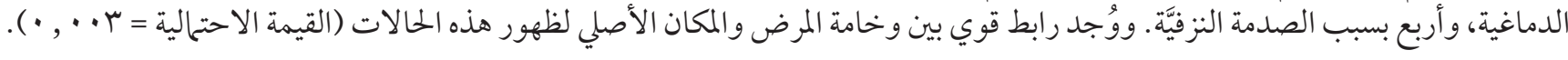

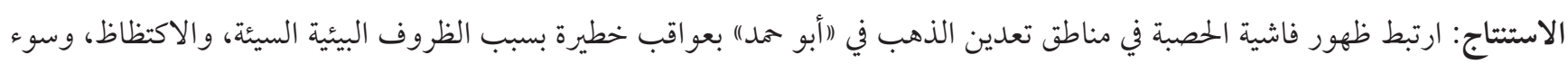

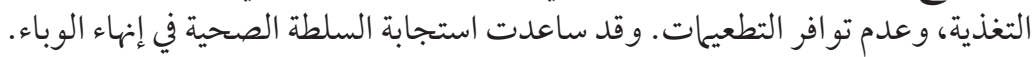

\section{References}

1. Global eradication of measles: report by the Secretariat. Geneva: World Health Organization; 2010.

2. Shakoor S, Mir F, Zaidi A, Zafar A. Hospital preparedness in community measles outbreaks challenges and recommendations for low-resource settings. Emerg Health Threats J. 2015; 8:24173. https://doi.org/10.3402/ehtj.v8.24173

3. Measles vaccines: WHO position paper - April 2017? Wkly Epidemiol Rec. 2017;92(17):205-27.

4. Liu F, Enanoria W, Zipprich J, Blumberg S, Harriman K, Ackley S, et al. The role of vaccination coverage, individual behaviors, and the public health response in the control of measles epidemics: an agent-based simulation for California. BMC Public Health. 2015;15:447. https://doi.org/10.1186/s12889-015-1766-6

5. Gastanaduy PA, Redd SB, Clemmons NS, Lee AD, Hickman CJ,Rota PA, et al. In: Roush SW, McIntyre L, Baldy LM, editors. Manual for the surveillance of vaccine-preventable diseases. Sixth edition. Atlanta (GA): Centers for Disease Control and Prevention; 2013:1-21 (http://www.cdc.gov/vaccines/pubs/surv-manual/chpto7-measles.pdf, accessed 23 December 2016).

6. Part II. Definitions. In: Response to measles outbreaks in measles mortality reduction settings: immunization, vaccines and biologicals. Geneva: World Health Organization; 2009:5-7 (https://apps.who.int/iris/bitstream/handle/10665/70047/WHO_ IVB_09.03_eng.pdf?sequence=1, accessed 18 June 2019).

7. Dabbagh A, Laws RL, Steulet C, Dumolard L, Mulders MN, KretsingerK, et al. Progress toward regional measles eliminationworldwide, 2000-2017. MMWR Morb Mortal Wkly Rep. 2018;67:1323-9. http:// doi.org/10.15585/mmwr.mm6747a6

8. Meeting of the International Task Force for Disease Eradication, November 2015. Wkly Epidemiol Rec. 2016;91(6):61-72.

9. Measles. Fact sheet. Geneva: World Health Organization; July 2017. (https://www.who.int/news-room/fact-sheets/detail/measles, accessed 2 July 2019).

10. Measles vaccines: WHO position paper - April 2017. Wkly Epidemiol Rec. 2017;92(17):205-27.

11. Curtale F, Perrelli F, Mantovani J, Atti MC, Filia A, Nicoletti L, et al. Description of two measles outbreaks in the Lazio Region, Italy (2006-2007). Importance of pockets of low vaccine coverage in sustaining the infection. BMC Infect Dis. 2010;10:62. https:// doi.org/10.1186/1471-2334-10-62

12. Sugerman DE, Barskey AE, Delea MG, Ortega-Sanchez IR, Bi D, Ralston KJ, et al. Measles outbreak in a highly vaccinated population, San Diego, 2008: role of the intentionally under vaccinated. Pediatrics. 2010; 125(4):747-55. https://doi.org/10.1542/ peds.2009-1653

13. Guidelines for measles and rubella outbreak investigation and response in the WHO European Region. Copenhagen: World Health Organization Regional Office for Europe; 2013 (http://www.euro.who.int/_data/assets/pdf_file/0003/217164/OutbreakGuidelines-updated.pdf, accessed: 20 October 2017).

14. WHO guidelines for epidemic preparedness and response to measles outbreaks. Geneva: World Health Organization; 1999 (https://www.who.int/csr/resources/publications/measles/whocdscsrisr991.pdf?ua=1, accessed 18 June 2019).

15. Sudan household survey, second round 2010. Summary report 2011. Khartoum: National Ministry of Health \& Central Bureau of Statistics; 2011 (https://reliefweb.int/sites/reliefweb.int/files/resources/MICS4_Sudan_2010.pdf, accessed 20 December 2016).

16. Coronado F, Musa N, El Tayeb EA, Haithami S, Dabbagh A, Mahoney F, et al. Retrospective measles outbreak investigation: Sudan, 2004. J Trop Pediatr. 2006;52(5):329-34. https://doi.org/10.1093/tropej/fmlo26

17. Sudan: WHO and UNICEF estimates of immunization coverage: 2016 revision (http://data.unicef.org/wpcontent/uploads/country_profiles/Sudan/immunization_country_profiles/immunization_sdn.pdf, accessed 19 October 2017).

18. Sudan: WHO statistical profile. Geneva: World Health Organization; January 2015 (https://www.who.int/gho/countries/sdn. pdf?ua=1, accessed 10 October 2017).

19. Measles. In: Hamborsky J, Kroger A, Wolfe S, editors. Epidemiology and prevention of vaccine-preventable diseases. The pink book: course textbook, 13th edition. Atlanta: Centers for Disease Control and Prevention; 2015 (https://www.cdc.gov/vaccines/ pubs/pinkbook/downloads/meas.pdf, accessed 10 October 2017).

20. Wadi EIA, Alredaisy SMAH. Socioeconomic and environmental implications of traditional gold mining in Sudan: the case of Barber Locality, River Nile State. Am Based Res J. 2015;4(7):1-11. https://doi.org/10.5281/zenodo.3429115

21. Annual health statistical report 2015. Khartoum: Ministry of Health; 2015 (http://www.fmoh.gov.sd/yearlyReports/Annual2015. pdf, accessed 24 December 2016).

22. Measles. Disease surveillance. World Health Organization Regional Office of Eastern Mediterranean [webpage] (http://www. emro.who.int/health-topics/measles/disease-surveillance.html, accessed 24 December 2016). 
23. Principal of epidemiology in public health practice, third edition. An introduction to applied epidemiology and biostatistics. Atlanta (GA): Centers for Disease Control and Prevention; 2006.

24. Dabbagh A, Patel MK, Dumolard L, Gacic-Dobo M, Mulders MN, Okwo-Bele JM, et al. Progress toward regional measles elimination - worldwide, 2000-2016.Wkly Epidemiol Rec. 2017;66(42):1148-53.

25. Wichmann O, Siedler A, Sagebiel D, Hellenbrand W, Santibanez S, Mankertz A, et al. Further efforts needed to achieve measles elimination in Germany: results of an outbreak investigation. Bull World Health Organ. 2009;87(2):108-15. https://doi. org/10.2471/blt.07.050187

26. Hersh BS, Tambini G, Nogueira AC, Carrasco P, de Quadros CA. Review of regional measles surveillance data in the Americas, 1996-99. Lancet. 2000;355(9219):1943-8. https://doi.org/10.1016/So140-6736(00)02325-4

27. Measles vaccines: WHO position paper, April 2017 - Recommendations. Vaccine. 2019;37(2):219-222. https://doi.org/10.1016/j. vaccine.2017.07.066

28. Grais RF, Conlan AJ, Ferrari MJ, Djibo A, Le Menach A, Bjørnstad ON, et al. Time is of the essence: exploring a measles outbreak response vaccination in Niamey, Niger. J R Soc Interface. 2008;5(18):67-74. https://doi.org/10.1098/rsif.2007.1038 